\title{
Challenging Binaries in Migration: The Role of the Environment in Mobility
}

\author{
Azin Emami \\ York University, Toronto, Canada,aziemami@gmail.com
}

\begin{abstract}
The rise in global temperatures and extreme weather events has affected agricultural trends throughout the world and threatened the livelihoods of entire communities. Although not a determinant on its own, environmental degradation constitutes one of the overlooked causes of mass displacement in the 21 st century. This paper critically examines the notion of 'environmental refugees' and its linkages with the formation of new forms of precarious labor in the Global South. The aim of this paper is to survey the available literature on environmental migration in order to explore some of the humanitarian consequences of anthropogenic climate change. More specifically, this paper works with the myth of 'invasion' by environmental refugees in order to understand the systemic nature and demographic characteristics of population displacements related to the erasure of the means of survival, land and work for communities en masse, compelling members of these communities to take severe risks for survival. Drawing on the available literature on climate change and migration patterns, this paper will consider the debate on international recognition for environmentally displaced persons (EDPs). Finally, the ways in which the international community can begin to respond to anthropogenic climate change and the associated ecological crises will be considered. The paper concludes that existing binaries in refugee law fail to capture the intricate relationship between social, economic, political and environmental factors in human mobility, leaving many environmentally displaced people without protection. In order to overcome this oversight, we must critically analyze existing categories and prioritize the voices and lived experiences of those impacted by environmental change.
\end{abstract}

KEYWORDS: displacement, environmental change, environmental refugees, precarious labour, the Anthropocene

\section{Introduction}

Anthropogenic climate change and the associated environmental crises are increasingly identified as realities of the $21^{\text {st }}$ century. While there is mounting evidence to support the science of global warming and the implications of climate change for our planet, the social and human rights dimensions of climate change are given little consideration. Environmental conditions were initially recognized in the first theories of migration elaborated at the end of the $19^{\text {th }}$ century, however, they soon began to be undermined in succeeding theories (Ionesco, Mokhnacheva and Gemmene 2017, 2). Current migration polices continue to be shaped by a binary understanding of migration inherited from the post-war years.

Migrants are often placed in rigid and dichotomous categories in which the extent of volition and coercion involved in their mobility decisions play a vital role in refugee status determination (Bose and Lunstrum 2014, 8). International recognition is granted to those who are forced to flee for political reasons, while those who move for other reasons are considered migrants, with responsibility for their reception falling solely on individual states, rather than the international community. The underlying binarism in migration policies resurfaced in the summer of 2015, during Europe's 'migration crisis', and has served to justify policies of exclusion and constraint (Crawley and Skleparis 2018, 48). It is important to note that the number of asylum seekers attempting to enter Europe is much smaller than those internally displaced in Syria and those in surrounding regions. During Europe's 'migration crisis', there was an estimated 6 million internally displaced people (IDPs) in Syria and about 5 million Syrian refugees in Jordan, Lebanon and Turkey, while the number of asylum seekers attempting to enter Europe in 2015 was about 1.3 million (Connor 2016). Nevertheless, governments and media have reinforced the sense of a crisis and strengthened the distinction between 'refugees' and 'migrants', with a strong preference for the latter (UNHCR 2016). The reality of migratory patterns, in which political, economic and environmental factors are intricately intertwined has been systematically overlooked in prevailing migration policies. 


\section{The environmental change-migration nexus}

Numerous sources corroborate that climate change poses profound consequences for human mobility (Martin 2017, 188). The fifth Assessment Report of the Intergovernmental Panel on Climate Change (IPCC) projected that "climate change over the $21^{\text {st }}$ century [will] increase [the] displacement of people." (IPCC 2014, 20). Moreover, the IPCC projects that "extreme weather events provide the most direct pathway from climate change to migration" but in the longer term, "sea level rise, coastal erosion, and loss of agricultural productivity will have a significant impact on migration flows" (Adger et al. 2014, 767-769, cited in Martin 2017). Some sources suggest that the number of people seeking refuge from environmental degradation is growing more rapidly than any other refuge-seeking group and that migration in response to environmental degradation is becoming the most pervasive form of forced migration (Aminzadeh 2006, 231).

The existential threat of climate change for coastal regions such as Bangladesh and the small Pacific islands present compelling cases in which the environmental change-migration nexus should be studied and addressed. Bangladesh has had a long history of extreme weather events, with devastating impacts resulting in mortalities in several instances (Findlay and Geddes 2011, 146). Bangladesh's climate change scientists and politicians concur that by 2050 , rising sea levels will inundate approximately $17 \%$ of the land and displace approximately 18 million people (Harris 2014).

In the case of the Pacific islands, the Intergovernmental Panel on Climate Change has concluded that sea level rise impacts on low-lying states of Kiribati, Tuvalu and the Marshall Islands may pose risks to the sovereignty and existence of these states (IPCC 2014). Some estimates suggest that Tuvalu could disappear in the next fifty years and its government has raised concerns about the potential for its complete submersion. Kiribati has similarly been preparing for the full submersion of its territory (Park 2011, 1).

In most instances, the environment interacts with political, social, economic and demographic processes to impact mobility decisions. However, in coastal regions such as Bangladesh and the small Pacific islands, environmental factors are more direct and immediate drivers of mobility. In these cases, severe environmental factors often exacerbate preexisting pressures, resulting in a tipping point, which would not have been otherwise reached (McAdam and Loughry 2009, 479).

Moreover, anthropogenic climate change has had disproportionate impacts on marginalized populations throughout the world. A group of scientists who have assessed population sensitivity to climate change have recognized that those who are directly engaged in primary production for their livelihoods will be much more affected than urban populations who gain living form secondary and tertiary activities (De Sherbinin et al. 2008). In the absence of any alternative means of securing a livelihood, labour migration has become a livelihood strategy for affected populations throughout the Pacific and Indian subcontinent.

In New Zealand, The Recognized Seasonal Employers Scheme (RSE) was introduced in order to assist employers in particular industries that attract seasonal workers from the Pacific islands. Similarly, the Kafala system in the Gulf region of the Middle East relies on labour from India, Nepal, Bangladesh and the Philippines, all places that are deeply impacted by environmental pressures. In both these instances, the needs of employers are prioritized and migrants are accepted temporarily on economic grounds, largely to fill employment gaps. Under these conditions, migrants are often exploited, subjected to discrimination and denied basic rights.

It is important to take note of a common dynamic in displacement in which populations forced to migrate end up in areas that are difficult and dangerous to survive in. Adding further complexity to existing patterns, another phenomenon is emerging in which people are being forced to migrate by non-climate factors into highly climate-vulnerable areas. This is happening in Bangladesh, where Rohingya refugees have ended up in areas of Bangladesh that are most impacted by climate factors such as monsoons, cyclones and rising sea levels (Randall 2018).

In the Syrian case, prolonged drought has been identified by numerous sources as a factor that has exacerbated tensions, contributing to the 2011 demonstrations against the Assad regime, which in turn 
resulted in the prolonged conflict that has displaced millions of people (Kelley et al. 2015; De Châtel 2014). The nuances within these examples demonstrate that it is increasingly difficult to identify individual drivers of mobility. In many cases, complex interactions between multiple factors have resulted in various forms of movement. Moreover, as noted by Crawley and Skleparis (2018), dominant representations of the European 'migration crisis' represent the flow of people heading towards Europe as linear and uninterrupted. In reality, many of those arriving in Europe had been living for months or years in other countries. These observations are applicable to cases involving environmental degradation and the erasure of the means of survival, land and work for communities en masse. Climate change and environmental degradation are increasingly influencing patterns of migration in complex ways and compelling affected populations to take severe risks for survival. The resulting migration patterns are similarly non-linear and multi-causal and it is, therefore, difficult to place affected populations within existing categories.

\section{The debate on environmental refugees}

As the above case demonstrates, the rise in global temperatures and the accompanying ecological disasters have already begun to significantly reduce the productivity of many lands and accelerated the urbanization process. While it is foreseeable that the majority of movements motivated by climate change and environmental degradation will occur within countries, urban capitals are increasingly inhospitable to those seeking protection from ecological disasters. Thus, it is likely that climate change will trigger larger and more complex movements of populations, both within and across borders (Guterres 2008). In such instances, increased cross-border movement is also a possible outcome.

Despite growing recognition of the role of the environment in migration, particularly since the middle of the 2000s, there is still reticence in recognizing environmentally displaced persons as refugees. The term 'environmental refugees' was first popularized in the 1970s by Lester Brown of the Worldwatch Institute, and appeared in El-Hinnawi's (1985) research in Kenya (Jacobson 1988). Findlay and Geddes's bibliometric analysis demonstrates that the term became increasingly pervasive in the 1990s with the publication of estimates of the global scale of potential refugee flows (Findlay and Geddes 2011, 140).

There has since been great debate concerning the use of the term, with social scientists and academics instead employing terms such as 'climate change-induced mobility,' 'environmentally-induced population displacement' and 'environmental migration' (Ibid. 141). There are numerous reasons for the reluctance to extend the refugee status to movements associated with environmental change. First, several sources have convincingly argued that environmental change is just one of many drivers of mobility and that the environment has the greatest impact on mobility where there are deeper underlying causes associated with political economic, sociological and demographic processes, this is particularly true for slow-onset events (Hugo 2008). Other sources have argued that the extension of the category could undermine the international legal regime for protection of conventional refugees.

On the other hand, some sources have argued that environmentally displaced persons should be recognized as refugees. For example, Jessica B. Cooper $(1998,486)$ has argued that environmental refugees fall within the definition of the Refugee Convention and deserve official refugee status, as well as the accompanying protections from all nations signatory to the Refugee Convention. Similarly, Biermann and Boas (2010) problematize the need to reserve the term 'refugee' for a category of people who needed immediate recognition in the aftermath of the Second World War and the subsequent tendency to invent less appropriate terms for new categories of people, who are currently being forced to flee their homes. Chimni has also argued that the condition of a 'well-founded fear of persecution' - that lies at the heart of the Refugee Convention - has meant that most third world refugees will continue to remain de facto excluded from the existing refugee regime, since their departure is often caused by natural disasters, war, or political turmoil, rather than by persecution (Chimini 2000, 7).

Returning to the aforementioned dichotomy between migrants and refugees, some sources have been critical of efforts to privilege refugees over migrants and have argued that this serves to reinforce, rather 
than challenge the dichotomy's flawed foundations. The fact that the environment is just one of many drivers of mobility does not mean that is should be overlooked. In fact, the above cases demonstrate that environmental factors are increasingly impacting migration patterns and it can be argued that mobility, in general, is a multi-causal phenomenon. Thus, the role of environmental factors in mobility should be considered in conjunction with other drivers of mobility.

Moreover, it is important to prioritize local perceptions of appropriate coping strategies and to see local populations impacted by environmental change as impactful agents in shaping new futures for themselves (Findlay and Geddes 2011, 153). Here it is useful to consider McAdam and Loughry's research on climate change in the Pacific islands. Their research in Kiribati and Tuvalu reveals that the term 'refugee' evokes a sense of helplessness and lack of dignity. These negative associations with the refugee status are traced back to the broader failures of the international system in providing adequate protection for refugees and other displaced people. This includes a failure of many nations to provide adequate assistance and accommodation, leaving millions of refugees in camps for extended periods, living precarious lives.

While Kiribati and Tuvalu face similar challenges, their responses to an impending climate change crisis have been distinct. The president of Kiribati has tried to secure opportunities for labour migration in Australia and New Zealand, so that those who are willing and able to move have an early opportunity to do so (McAdam and Loughry 2009, 476). This would result in more gradual resettlement and would ease the transition process if and when the entire population has to relocate. In Tuvalu, however, that there is a preference for emissions reductions and a refusal to accept that migration or climate refugee protection alone are sufficient responses to the complex changes that are underway in small islands (Farbotko and Lazrus 2012, 12).

Perhaps more fittingly, Canefe (2017) has introduced the notion of 'migration as necessity' to describe situations in which populations must leave their homelands out of necessity, often as a result of extreme conditions, such as poverty. This definition could be applicable to those populations whose livelihoods are threatened by environmental factors. In many instances, migration in response to environmental factors is not a failure to adapt and should instead be considered as an adaption strategy. The lack of consensus on the appropriate term for populations impacted by environmental degradation, along with the fact that migration could act as a climate change adaptation solution calls into question the traditional dividing line between forced and voluntary migration (Ionesco, Mokhnacheva and Gemmene $2017,2)$. This reality prompts us to re-consider the binary divisions between voluntary and involuntary movements and to address the disjuncture between conceptual and policy categories and the lived experiences of displaced populations (Crawley and Skleparis 2018, 48).

\section{Conclusion}

The above analysis demonstrates the complex interplay between the environment and other processes in shaping displacement patterns, which in turn increasingly problematize the use of exclusive binaries in dominant migration policies. The distinction between refugees and migrants often fails to capture the complexity of existing patterns of movement. Although the environment is often just one of many drivers of mobility, it should not be overlooked as contributing factor in mobility decisions. The lacunae that exist within the international legal system in terms of effectively recognizing and responding to the needs of environmentally displaced persons have exacerbated the challenges that displaced populations are faced with. Rather than endorsing top-down policies that serve to discourage out-migration, we must instead critically examine the implications of binary categories in migration policies and consider the ways in which various factors overlap and intersect to impact mobility decisions. 


\section{References}

Adger, W. Neil et al. 2014. "Human Security" In Climate Change 2014: Impacts, Adaptation, and Vulnerability. Contribution of Working Group II to the Fifth Assessment Report of the Intergovernmental Panel on Climate Change, pp. 755-791. Cambridge: Cambridge University Press.

Aminzadeh, Sara C. 2006. "A moral imperative: The human Rights Implications of Climate Change." Hastings Int'l \& Comp. L. Rev. 30: 231-265.

Biermann, Frank, and Ingrid Boas. 2010. "Preparing for a warmer world: Towards a Global Governance System to Protect Climate Refugees." Global Environmental Politics 10 (1):60-88.

Bose P., and E. Lunstrum. 2014. "Introduction Environmentally Induced Displacement and Forced Migration." Refuge 29 (2): 5-10.

Canefe, Nergis. 2017. "Migration as Necessity: Contextualizing The European Response to the Syrian Exodus." Refugee Watch 47:120.

Chimni, S. Bhupinder. 2000. "Globalization, Humanitarianism and the Erosion of Refugee Protection." Journal of Refugee Studies 13(3):7.

Cooper, Jessica B. 1998. "Environmental refugees: Meeting the Requirements of the Refugee Definition." NYU Envtl. LJ 6: $\quad 480-$ 529.

Connor, Philip. 2016. "Number of Refugees to Europe Surges to Record 1.3 Million in 2015." Pew Research Centre. http://www.pewglobal.org/2016/08/02/number-of-refugees-to-europe-surges-to-record-1-3-million-in-2015/

Crawley, Heaven, and Dimitris Skleparis. 2018. "Refugees, Migrants, Neither, Both: Categorical Fetishism and the Politics of Bounding in Europe's 'Migration Crisis'." Journal of Ethnic and Migration Studies 44 (1): 48-64.

De Châtel, Francesca. 2014. "The Role of Drought and Climate Change in the Syrian uprising: Untangling the Triggers of the Revolution." Middle Eastern Studies 50 (4): 521-535.

De Sherbinin, et al. 2008. "Rural Household Demographics, Livelihoods and the Environment." Global Environmental Change 18 (1): $38-53$.

El- Hinnawi, E. 1985. Environmental Refugees. Nairobi. UN Environmental Programme.

Farbotko, Carol, and Heather Lazrus. 2012. "The First Climate Refugees? Contesting Global Narratives of Climate Change in Tuvalu." Global Environmental Change 22 (2): 382-390.

Findlay, Allan, and Alistar Geddes. 2011. "Critical Views on the Relationship between Climate Change and Migration: Some Insights from the Experience of Bangladesh.” In Migration and Climate Change edited by Etienne Piguet, Antoine Pecoud and Paul de Guchteneire. New York: Cambridge University Press.

Gardiner, Harris. 2014. "Borrowed Time on Disappearing Land." The New York Times, March 28, 2014. https:/www.nytimes.com/2014/03/29/world/asia/facing-rising-seas-bangladesh-confronts-the-consequences-of-climatechange.html?_r $=0$.

Guterres, António. "Climate Change, Natural Disasters and Human Displacement: A UNHCR Perspective." UNHCR. http://www.unhcr.org/4901e81a4.pdf.

Hugo, G. 1996. “Environmental Concerns and International Migration.” International Migration Review 30 (1): 105-131.

Ionesco, Dina, Daria Mokhnacheva, and François Gemenne. 2017. The Atlas of Environmental Migration. New York: Routledge.

IPCC. 2014. "Summary for Policymakers" In Climate Change 2014: Impacts, Adaptation and Vulnerability. Part A: Global and Sectoral Aspects. Contribution to Working Group II to the Fifth Assessment Report of the Intergovernmental Panel on Climate Change, edited by Field, Christopher B. et al., 1-32. Cambridge: Cambridge University Press.

Jacobson, J. 1998. Environmental Refugees: A Yardstick of Habitability. Washington DC, World Watch Institute (World Watch Paper 86).

Kelley, Colin, P. et al. 2015. "Climate Change in the Fertile Crescent and Implications of the Recent Syrian Drought." In Proceedings of the National Academy of Sciences of the United States of America, edited by Brian Jon Hoskins. 112 (11): 3241-3246.

Martin F. Susan. 2017. "Environmental Change and Human Mobility: Trends, Law and Policy” Comparative Population Studies 42: $187-218$.

McAdam, Jane, and Maryanne Loughry. 2009. "We Aren’t Refugees." Inside Story (29): 466-475.

Park, Sosin. 2011. "Climate Change and the Risk of Statelessness: The Situation of Low-Lying Island States." UNHCR 1-23.

Randall, Alex. 2018. "Stateless, and At Risk of the Weather." Le Monde Diplomatique, May 22, 2018.https://mondediplo.com/outsidein/stateless-and-at-risk-of-the-weather.

UNHCR. 2008. "Climate Change, Migration and Displacement: Who Will Be Affected?" Working Paper submitted by the informal group on Migration/Displacement and Climate Change of the IASC - 31 October 2008. http://www.unhcr.org/protection/environment/4a1e4fb42/climate-change-migration-. 